\title{
Analysis of the Teaching Effect of the Normal Human Morphology with Mixed Teaching Mode and Formative Evaluation in China
}

\author{
Análisis del Efecto de la Enseñanza de Morfología Humana Normal \\ con un Modelo de Enseñanza Mixta y Evaluación Formativa en China
}

Meng Xiaotong; Chen Wujin; Liao Libin; Li Tian; Qin Wen \& Bai Shengbin

LIAO, L.; MENG, X.; CHEN, W.; LI, T.; QIN, W. \& BAI, S. Analysis of the teaching effect of the Normal Human Morphology with mixedteaching mode and formative evaluation in China. Int. J. Morphol., 37(3):1085-1088, 2019.

SUMMARY: With the accumulation of teaching experience and the summary of the teaching process in the teaching of medical colleges and universities, the course "Normal Human Morphology" has been basically on the right track in undergraduate education. However, most of the colleges and universities in China still use the traditional teaching mode, and the evaluation of students' learning effects and teacher teaching still follows the method of final evaluation. This method is not conducive to students' timely understanding of self-stage learning effects. It will affect the teacher's adjustment (or solution) to the specific links (or problems) that appear in the teaching process. The establishment of the mixed teaching model and formative evaluation system can solve the problems of the two to some extent.

KEY WORDS: Normal Human Morphology; Mixed teaching mode; Formative evaluation.

\section{INTRODUCTION}

"Normal Human Morphology" is widely practiced in most medical schools in China as a fusion course. The course is based on the integration of human anatomy and two courses of histology and embryology. This course has begun to take shape from the initial formal integration, to the interspersed integration, to the overall integration of the curriculum (Na, 2008; Chen et al., 2013). With the rapid development of network technology, the use of new technologies and new methods has quietly changed the teaching mode. In the past, the traditional teaching mode was gradually affected by the new teaching mode. "Normal Human Morphology" is also used in the teaching process to apply a variety of new teaching methods, such as Cloud Board, Internet + , DBL, flip classroom, etc., but most of them are only a part of the course of disassembly and single teaching. The addition of means cannot satisfy students' mastery and understanding of the knowledge system. The concept of the hybrid teaching model is proposed (Xu et al., 2015; Bai et al., 2017).

Development of a mixed teaching model: The development of mixed teaching is derived from the combination of the original traditional face-to-face teaching mode and the simple online teaching mode ( $\mathrm{He}, 2005)$. The traditional teaching mode has the disadvantages of supplementing new knowledge and poor concrete display of abstract concepts, while the simple online teaching mode is not enough in terms of student supervision, classroom feedback, and knowledge system coherence. The development of the hybrid teaching model can compensate and solve different degrees of problems in the development of these two teaching modes. The mixed teaching mode is based on the traditional face-to-face teaching mode, using computer, mobile phone, Internet and other technologies to integrate digital teaching content, plus extracurricular knowledge and virtual digital laboratory development, the instructor will "normal human body Morphology" guides students to complete the compulsory content specified in the syllabus during class, and at the same time gives students the extracurricular learning content that the students need to complete the online course, and finally allows the students to complete the course majors under the guidance of the teacher. Master and explore the learning content related to this course. Complete the construction of the knowledge 
system online, and complete the expansion of the course under the line, but this is not a simple addition of the two, but the use of information and communication technology and the Internet platform while improving the level of conciseness of the instructors. Let the Internet and the medical profession deep integration, thus creating a new ecosystem of new developmental medical teaching models. The formation process of the hybrid teaching model course: the analysis of the knowledge needs of students and teachers, the analysis of the current situation of the curriculum, the integration of theoretical courses, the improvement of the online curriculum, and the promotion of the course lasted for 8 years (Lü et al., 2014; Chen et al., 2017).

The establishment of formative evaluation: Formative evaluation is a complete evaluation system composed of students' demand feedback, staged learning feedback, teaching feedback and final evaluation in the whole process of "Normal Human Morphology". Through this stage, the teacher can be based on the student stage. Sexual learning feedback and knowledge mastery and interest, etc., timely adjust the teaching progress, teaching mode and other methods of teaching methods suitable for students to receive and master (Yang, 2007). That is, the questionnaire will be distributed before the start of the first class to understand the content of the students' desire to learn, the way to receive the lessons, and the level of understanding of the course, so that the instructors can do well before preparing for the lesson and teaching. Adequate preparation; set up information staff in the class, timely feedback on the knowledge that the students in the same class do not understand, and the way the teacher teaches, and put it through the whole process of teaching; after the start of the class, each class is in front of the class. The knowledge learned in the course is tested as a normal test (about $5 \%$ ).the teacher needs a paperless test (about $10 \%$ ) in the mid-term exam, and then analyzes the grades of the course to understand the weak links of the students' learning; At the end of the semester, students will be surveyed on the appropriateness of the teaching methods taught by the teachers, the acceptance of the curriculum, and opinions and suggestions for the course. The final exam will be conducted in an oral exam (about $60 \%$ ) + written exam (about $15 \%$ ) + practical skills (about $10 \%$ ).

\section{MATERIAL AND METHOD}

The specific implementation process is as follows: In the class that provides the "Normal Human Morphology" course, all the students of the 2016 Undergraduate Nursing School 2016 are selected, and the teaching mode adopts the mixed teaching mode + formative evaluation to teach them.
The control group is the class that ends the evaluation using the traditional teaching mode (the nursing degree of the course that has been carried out in the past 10 years, that is, grade 2009-2016), and the scores of the failed students are excluded. After collecting the data, it is tested for normality and homogeneity of variance (excluding the class that does not obey the normal distribution), and the variance analysis of the single-factor multiple comparison of the grades of the grades that are subject to the distribution of the positive and the grades of the "2016 normal human morphology" (at a level of $\mathrm{a}=0.05)$. A total of 15 classes, 6 grades, of which 09 grade-11 is the curriculum development stage (teaching in the traditional teaching mode); 14 grade-15 is the curriculum integration phase (teaching in the mixed teaching mode); 16 is the course Development stage (mixed teaching + formative evaluation teaching mode teaching).

\section{RESULTS}

The results are shown in Tables I and II. At the same time, the statistical analysis results of the questionnaires on the self-learning evaluation and the new teaching mode survey of the "normal human morphology" course of the 2016 students at the end of the semester are shown in Table III.

The formation stage score is $67.55 \pm 12.72$, the fusion stage score is $72.79 \pm 10.93$, and the development stage score is $83.94 \pm 9.58$. The scores of the three stages are normal test. The $\mathrm{P}$ value is greater than 0.05 (according to the level of $>=0.05$ ): formation Phase $\mathrm{P}=0.054$, fusion phase $\mathrm{P}=0.061$, development phase $\mathrm{P}=0.093$, and it is considered that the three-stage performance approximates the positive distribution. The homogeneity test of variance is $\mathrm{P}=0.019$. According to the level of $>=0.05$, the variance of the three stages cannot be considered as the same. Therefore, Tamhane's T2 and Dunnett's test can be used to obtain the P value of the normal human morphological comprehensive analysis of each stage. (According to the level of $<=0.05$ ), it is considered that the difference between the two-stage comprehensive scores is statistically significant.

\section{DISCUSSION}

The comparison of the traditional teaching mode + final evaluation teaching method and the mixed teaching mode + formative evaluation teaching method in the actual teaching can provide a basis for the application of the new teaching mode of other fusion courses in the future. By comparing the statistical analysis of the comprehensive 
Table I. Statistical description of the comprehensive human morphological comprehensive results at different stages.

\begin{tabular}{lccccc}
\hline \multicolumn{1}{c}{ stages } & Mean & $\begin{array}{c}\text { Standard } \\
\text { deviation }\end{array}$ & $\begin{array}{c}\text { Standard } \\
\text { error }\end{array}$ & \multicolumn{2}{c}{ 95\% confidence interval } \\
Lower limit & Upper limit \\
\hline Formation stage & 67.55 & 12.72 & 0.81 & 65.95 & 69.15 \\
Fusion phase & 72.79 & 10.93 & 0.94 & 70.94 & 74.63 \\
Development stage & 83.94 & 9.58 & 0.84 & 81.09 & 86.79 \\
\hline
\end{tabular}

Table II. Analysis of variance of normal human morphological comprehensive results at different stages.

\begin{tabular}{|c|c|c|c|c|c|c|}
\hline \multirow{2}{*}{ stages } & \multirow{2}{*}{ stages } & \multirow{2}{*}{$\begin{array}{c}\text { Mean } \\
\text { difference }\end{array}$} & \multirow{2}{*}{ Standard error } & \multirow{2}{*}{$P$ value } & \multicolumn{2}{|c|}{$95 \%$ confidence interval } \\
\hline & & & & & Lower limit & Upper limit \\
\hline \multirow{2}{*}{ Formation stage } & Fusion & -5.24 & 0.84 & 0.000 & -8.2 & -2.26 \\
\hline & Development & -16.39 & 0.96 & 0.000 & -20.37 & -12.41 \\
\hline \multirow{2}{*}{ Fusion phase } & Formation & 5.24 & 0.84 & 0.000 & 2.26 & 8.21 \\
\hline & Development & -11.15 & 0.92 & 0.000 & -15.29 & -7.02 \\
\hline \multirow{2}{*}{ Development stage } & Formation & 16.39 & 0.86 & 0.000 & 12.41 & 20.37 \\
\hline & Fusion & 11.15 & 0.92 & 0.000 & 7.02 & 15.29 \\
\hline
\end{tabular}

Table III. Self-learning effect evaluation and new teaching mode survey.

\begin{tabular}{|c|c|c|c|}
\hline Questionnaire project & Yes & No & General \\
\hline I am more acceptable to the teacher's teaching method. & $103(0.56)$ & $20(0.16)$ & $61(0.33)$ \\
\hline $\begin{array}{l}\text { The online course content arranged by the teacher after } \\
\text { class is easy to understand. }\end{array}$ & $144(0.78)$ & $3(0.02)$ & $37(0.20)$ \\
\hline Pre-class small test is helpful for your self-study? & $121(0.66)$ & $17(0.09)$ & $46(0.25)$ \\
\hline $\begin{array}{l}\text { I hope tea chers will adopt a formative evaluation } \\
\text { system to evaluate students. }\end{array}$ & $139(0.76)$ & $22(0.12)$ & $23(0.13)$ \\
\hline Oral test can promote my hard work review & $94(0.51)$ & $36(0.20)$ & $54(0.29)$ \\
\hline $\begin{array}{l}\text { Does the experimental assessment link contribute to the } \\
\text { improvement of basic skills and the development of } \\
\text { collaboration skills? }\end{array}$ & $155(0.84)$ & $10(0.05)$ & $61(0.33)$ \\
\hline I hope other courses can also be taught in this way. & $95(0.52)$ & $33(0.18)$ & $56(0.30)$ \\
\hline $\begin{array}{l}\text { I have completely mastered what the teacher said in } \\
\text { class. }\end{array}$ & $47(0.25)$ & $40(0.28)$ & $97(0.53)$ \\
\hline
\end{tabular}

scores of students at different stages of the formation process of the course of the normal human morphology of the nursing profession, the overall mixed teaching model + formative evaluation pilot grade is slightly better than the non-pilot grade: curriculum development The stage performance is better than the course integration stage, and the course integration stage is better than the course formation stage. The overall development of the curriculum is becoming more and more mature. The new teaching mode is helpful to students who do not like to review in the normal learning mechanism. The change of the teaching method of the instructor makes the construction of the student's knowledge system relatively complete, and the full use of the classroom time enables the instructor to better and more clearly present the key difficulties and the framework of the course context; the content of the online course after class The layout is more comprehensive and enriches the content of this course. At the same time, it also leaves valuable classroom time to the students to master the key knowledge of the outline. However, because only one of the pilot grades may have certain limitations, and the determinants of students' higher grades are derived from the subjective judgments of the instructors and the examiners at the oral exams, as well as the uneven quality of students in each grade. The transformation of the new teaching model makes the curriculum still have some places to be explored in the initial evaluation, and the promotion of the hybrid human teaching model + formative evaluation teaching method in the future is also worthwhile to improve. 
Based on the characteristics of the integration of the "normal human morphology" course, the transformation and evaluation of the teaching mode is an urgent problem to be solved at this stage. The concept of "mixed teaching mode + formative evaluation" can solve this problem to some extent (He et al., 2016). Mixed teaching is a combination of a variety of teaching methods and the whole process of teaching the same course. Mixed teaching can improve the teaching method in the teaching mode, and a mixture of multiple means, multiple ways and multiple methods to make up d efects in teaching by a single means. Formative evaluation is to evaluate and feedback the development of things in the process of development or occurrence. The use of formative evaluation in the teaching process can help the instructors to understand the dynamics of students' knowledge and whether the specific teaching methods are used properly. To help students understand the recent learning situation and help teachers adjust the teaching methods in a timely manner. The new teaching mode of "mixed teaching mode + formative evaluation" enables teachers to apply new teaching methods to the course teaching in the teaching process, while formative evaluation can provide timely feedback in the process of teachers using the new teaching mode. The degree to which students adapt to new teaching methods and how to master knowledge of such methods. The long-standing traditional teaching mode has many flaws under the influence of the final evaluation, and the application of the new teaching mode allows the instructors to adjust the teaching plan according to the feedback of the students' staged learning in a timely manner, tailored to the way students receive. Develop a teaching method for it.

\section{ACKNOWLEDGMENTS}

The authors thank students in the 2016 intakes for their cooperation in this experiment.

LIAO, L.; MENG, X.; CHEN, W.; LI, T.; QIN, W. \& BAI, S. Análisis del efecto de la enseñanza de morfología humana normal con un modelo de enseñanza mixta y evaluación formativa en China. Int. J. Morphol., 37(3):1085-1088, 2019.

RESUMEN: Con la mayor experiencia de los docentes y del proceso de aprendizaje en la enseñanza de facultades y universidades de medicina, el curso "Morfología Humana Normal" básicamente ha seguido una metodología correcta en la educación de pregrado. Sin embargo, la mayoría de los colegios y universidades en China aún utilizan el modelo de enseñanza tradicional, por lo cual, la evaluación de los efectos de aprendizaje de los estudiantes junto con la enseñanza docente, a la fecha, sigue el método de una evaluación final. Este método no es propicio para la comprensión oportuna por parte de los alumnos, en la etapa del auto-aprendizaje, ya que afecta la adaptación (o solución) del profesor a los enlaces (o problemas) específicos que aparecen en el proceso de enseñanza. El establecimiento de un modelo de enseñanza mixta y un sistema de evaluación formativa en cierta medida podrían resolver ambos problemas.

PALABRAS CLAVE: Morfología Humana Normal; Modelo de enseñanza mixta; Evaluación formativa.

\section{REFERENCES}

Bai, S.; Guo, Q. \& Dong, J. Development and reflection of normal human morphology in teaching related Chinese medicine. Chin. J. Histochem. Cytochem., 25(1):93-5, 2017.

Chen, B.; Sun, E. \& Lu, L. Construction of multimedia morphology teaching platform based on MOOC (Medical Morphology). Basic Med. Educ., 19(2):151-3, 2017.

Chen, L.; Si, D.; Zhang, Y.; Sun, H. \& Gao, J. Reflections on the integrated teaching of human anatomy and histology and embryology knowledge by clinical medical students. Chin. J. Anat., 36(1):128-9, 2013.

$\mathrm{He}, \mathrm{K}$. Looking at the new development of educational technology theory from blending learning. J. Nat. Acad. Educ. Adm., 24(9):37-48, 2005.

$\mathrm{He}, \mathrm{K}$. ; Chen, W. \& Lu, X. Application of formative evaluation under hybrid teaching of human body structure. Basic Med. Educ., 18(4):255-9, 2016.

Lü, C.; Jiang, X. \& Tian, Y. Teaching design of integrated medical morphology morphology course. Basic Med. Educ., 16(2):79-81, 2014.

$\mathrm{Na}$, L. Application of RIA technology in medical morphology network teaching. Yangpu, Second Military Medical University, 2008.

$\mathrm{Xu}, \mathrm{X}$.; Li, D. \& Li, Y. Application of mixed teaching in medical education. China High. Med. Educ., (12)9:19-20, 2015.

Yang, B. Research on formative evaluation in the background of new curriculum. Shanghai Shi, Shanghai Normal University, 2007.

Corresponding author:

Bai Shengbin

Department of Histology and Embryology

Xinjiang Medical University

Xinyi Road 393

Urumqi, Xinjiang

CHINA

Email: bsbxx@126.com

Received: 27-09-2018

Accepted: 07-12-2018 